\title{
The price of oil: is it low and is that bad?
}

\section{James Bond and Charles Kenny}

\author{
The World Bank, 1818 H St. NW, Washington, DC 20433, USA \\ E-mail: ckenny@worldbank.org
}

\begin{abstract}
This paper is adapted from a speech given by James Bond at the International Energy Agency, 14 May 1998. The views expressed in this paper are those of the authors and should not be attributed in any manner to the World Bank, to its affiliated organisations, or to members of its board of executive directors or the countries they represent.
\end{abstract}

The long-term price of oil should rest near its long run marginal cost (LRMC). Past price history and both demand and natural supply factors suggest that an oil price in the low teens is closer to the LRMC than the prices experienced over most of the last 25 years. For oil producing countries, this low price might not be as damaging as is often supposed - and might indeed encourage higher long-term growth. For oil consumers, low prices offer the opportunity to reform markets and reduce subsidies, with positive impacts on electricity rollout, development and the environment. For oil companies, low prices suggest the need to create new profit opportunities, but some of the more flexible and competitive players have already begun to show that this is possible.

Keywords: Oil price; developing countries; energy sector reform.

Reference to this paper should be made as follows: Bond, J. and Kenny, C. (2002) 'The price of oil: is it low and is that bad?', Int. J. Global Energy Issues, Vol. 17, No. 4, pp.283-291.

Biographical notes: James Bond is director of the mining department of the World Bank Group. Previous experience includes running the telecommunications and energy unit of the World Bank and ten years in the international petroleum industry working on asset acquisition and divestiture; project finance; oil refining and product distribution; oil and gas field development; energy pricing and taxation.

Charles Kenny is an infrastructure economist in the ICT department of the World Bank Group. Previously, he worked in the World Bank's development economics department.

\section{The price of everything but the value of nothing}

Compared to other commodities, the amount of information about the price of every type of crude, distillate, quality or grade of oil, for decades past, is immense. But this tells us little about the 'true value' of these fuels. By 'true value' here, we mean the long run marginal cost (LRMC) of oil. At the 'right' price for oil, according to theory, we are investing enough to replace reserves and production capacity, but not over-investing at the expense of projects which would make a higher economic rate of return. 
The LRMC of oil is made up of three elements:

- The first is the technical cost of finding, producing, transporting, and refining crude oil and then distributing it to users. This includes the short run marginal cost (the cost of producing the last barrel), and a capital (or fixed) cost component.

- The second is the 'Depletion Premium', the cost of production and conversion to use of the best alternative energy source, discounted from the future date at which all oil is exhausted and the 'backstop material' enters production.

- The last comprises the external costs of the environmental and social impacts resulting from producing, transporting, refining and consuming oil - that is, these costs not directly borne by producers, shippers, refiners and consumers. Examples are the costs of maritime pollution, lead-induced IQ loss among children and global climate change due to $\mathrm{CO}_{2}$ emissions.

\subsection{LRMC and the current oil price}

Long-run marginal cost is the price that we would expect oil to trend towards in an efficient market. But it's next to impossible to calculate such a price in the presence of pervasive market distortions that one finds in the oil industry. These include cartels such as OPEC, protection of domestic markets, direct and indirect subsidies to production and use, sanctions and assorted other interventions. What we can say, however, is that most of these non-market actions are likely to raise the price of oil above the long run marginal cost. Allowing for structural changes in the cost of production and the nature of demand, then, prices have mostly been above long run marginal cost. Therefore, we can expect that the latest dip in the price cycle is likely to bring the price of oil closer to the long run marginal cost.

Figure 1 World oil prices, 1950 to 1997

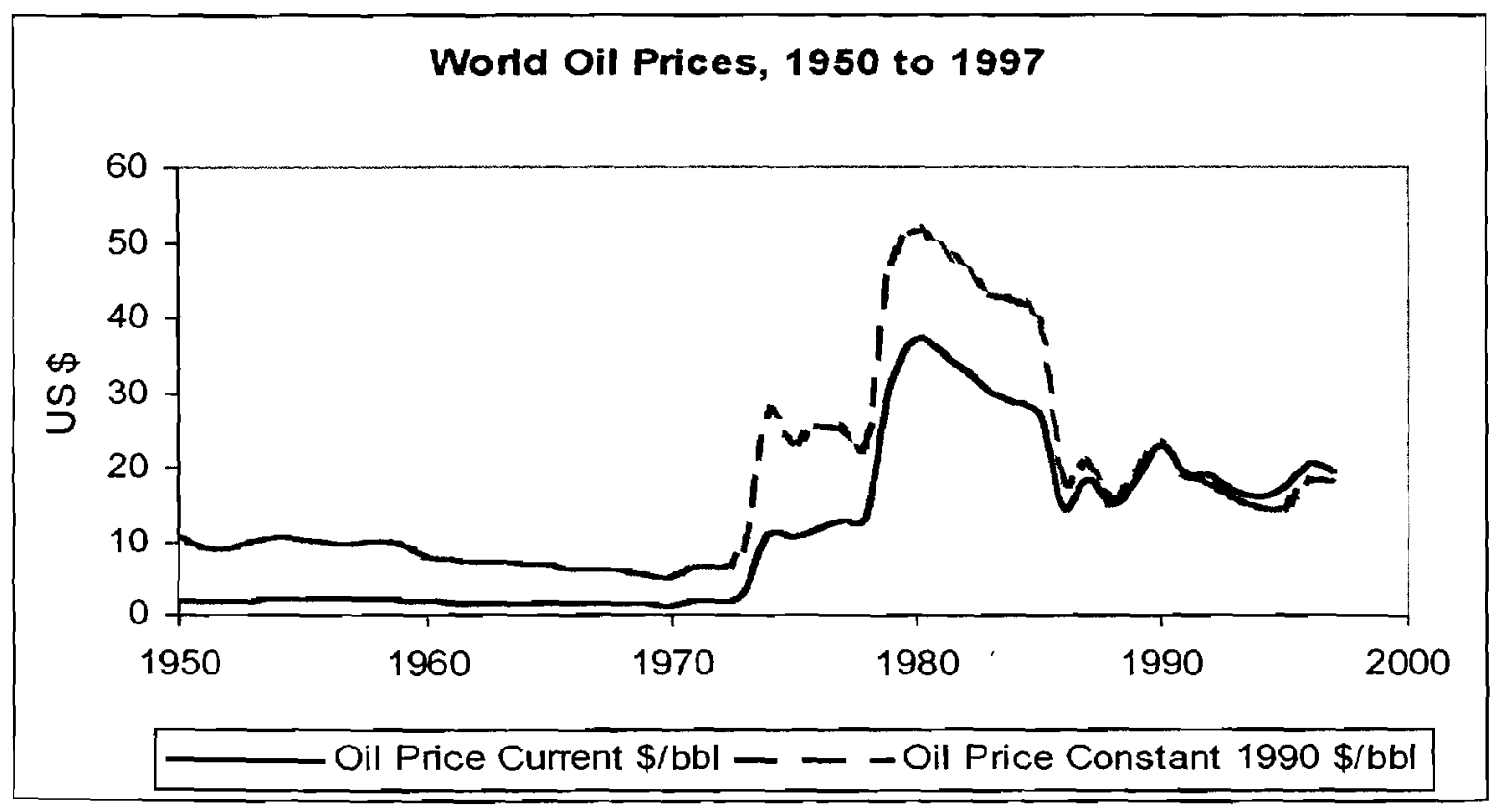

Source: World Bank Commodity Price Database 
What does this tell us about recent oil prices? Clearly, prices as low as they were in February 1999 , hovering around $\$ 13$ to $\$ 14$, are lower than they have been for quite a while (see Figure 1). Nonetheless, this price is more than a dollar higher than the real price of oil at any point prior to the first oil shock in 1973. Indeed, going from 1973 back as far as the First World War, the average price of oil in 1990 US currency remained close to $\$ 10$ per barrel. If we cannot find a reason to believe that the LRMC has greatly increased since 1973 , then, this suggests that an oil price of closer to $\$ 10$ per barrel is closer to the long run price than the prices that reigned during the 1980 s, and prices near $\$ 30$ a barrel that we have seen as recently as the end of 2000 .

\section{The price rise of 25 years ago}

We would argue that while there were significant changes in the oil market and the world economy following the early 1970s, and the net effect of these changes has clearly been to increase the price of oil in the world market, it's unlikely that the driving force behind these changes was any increase in the long-run marginal cost of oil extraction:

- First, this is because it is clear that the initial impetus behind the 1973 and 1979 increases in oil prices was geopolitical, not economic in nature.

- Second, sustained high prices are not the result of dwindling supplies creating conditions of scarcity. Indeed, since the 1960 s and 1970s, we have moved from dire predictions of energy exhaustion to concerns that, with ultimately recoverable fossil fuel reserves enough to last another 150 years, we could wreak catastrophe on the world's climate far before they run out [1].

- Third, high prices did not reflect any massive increase in the basic costs of extraction. In fact, we have observed the widespread entry of low cost operators worldwide, and new, much cheaper technology in areas like offshore production, seismic analysis, and refining. At the same time, while technology has squeezed recovery costs, financial hedging has lowered the cost of bearing risk.

Further, there is little evidence that rising oil prices were driven by massive increases in demand (see Figure 2). In fact, it is clear that the role of oil in world output has begun to shrink. From 1929 to 1970, oil production expanded far faster than World exports or Gross World Product, increasing over 1,000\%. This compares to a $330 \%$ increase in world exports of all goods and services, and a $270 \%$ increase in world GDP. But from 1970 to 1990 , global crude oil production increased by only one third, and oil exports increased just $20 \%$. This compares to total world exports of goods and services which expanded $140 \%$ and global GDP, which approximately doubled [2-4]. Today, the rate of decrease in oil use per unit of output value suggests that we might eventually see economic growth that is oil-demand neutral. 
Figure 2 Global oil production and GDP

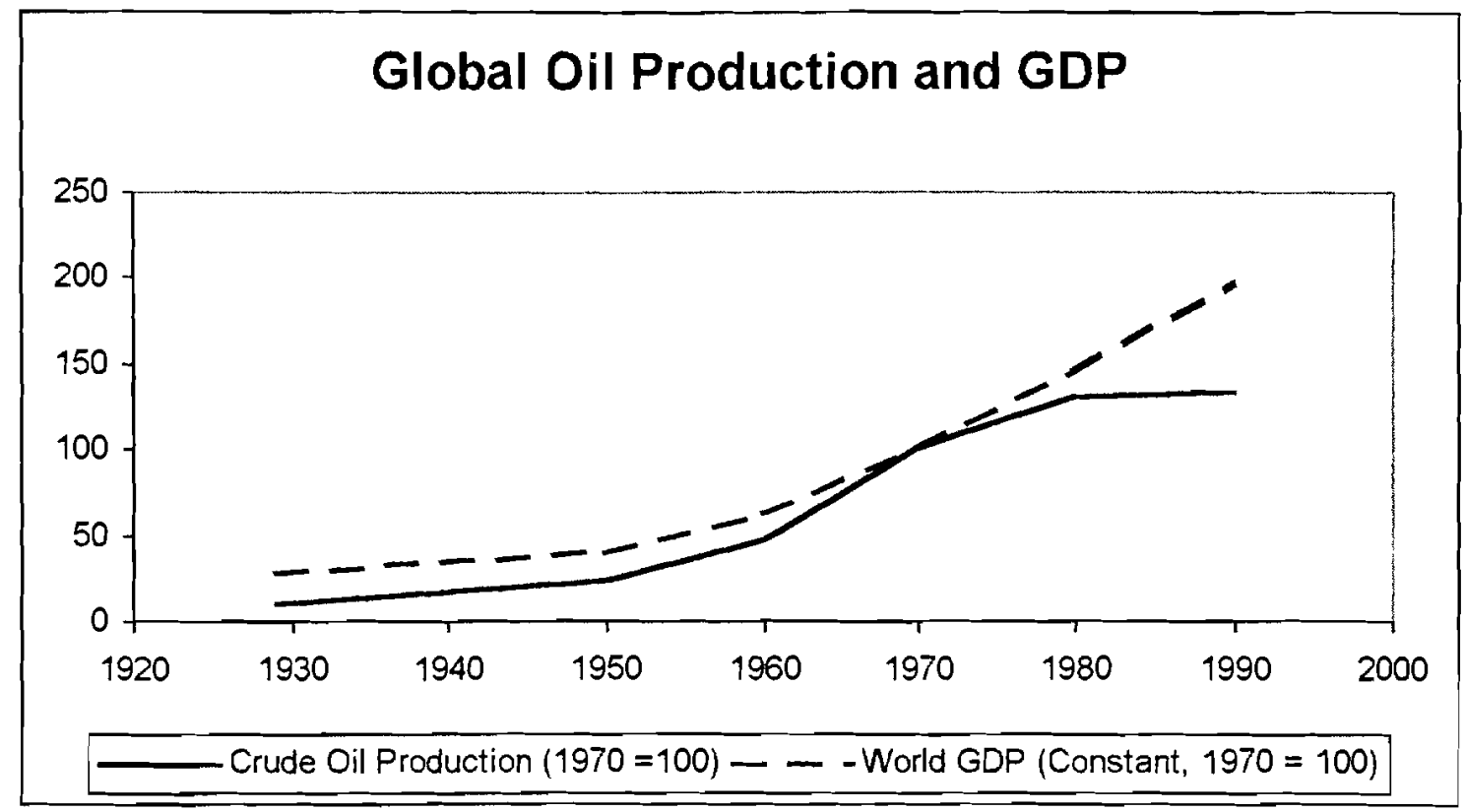

Sources: Maddison [2], Anderson [3] and DeGoyler and MacNaughton [4]

Oil is losing its paramount place in the world economy for three reasons. First, the world's production systems and output are becoming less reliant on energy. Second, the share of cartelised oil producers in the output of the energy sector is under threat, both from other energy sources and from increasing competition. Third, as the negative externalities of oil use (such as pollution and global warming) are taken into account in usage taxes, wellhead prices are coming under increasing pressure.

\subsection{Slackening demand}

Globally, growth in demand for energy is slacking, and it is clear that energy use per unit of output is dropping in the major economies of the world. In 1970 , each $\$ 1,000$ of OECD GDP took 0.18 tonnes of oil to produce. Today, that figure has dropped to 0.11 tonnes. The historical rate of decrease in energy use per unit of output value averaged about $1 \%$ from the mid Nineteenth Century until the 1970 s. Since then, this rate has increased to a $2 \%$ fall per annum in many of the advanced industrial countries, suggesting that we might soon see economic growth that is energy-demand neutral $[3,5]$. Already, the IEA estimates global energy demand growth will drop to below $1 \%$ per year between now and 2010 , this in response to greater energy efficiency and to changes in the structure of the world economy:

- In the medium term, as the massively distorted energy markets of Eastern Europe and the FSU become reformed they are likely to need much less energy. At the moment, the former Soviet Union consumes over $2 \mathrm{~kg}$ of oil equivalent per US dollar of GDP. This compares to $1.2 \mathrm{~kg}$ in India, 0.8 in East Asia, and between 0.2 and $0.4 \mathrm{~kg}$ in developed countries [6]. It is impossible to imagine that market reforms will not reduce this intensity of demand.

- And in the long term we are shifting away from industries that consume energy to make things, towards services, a far less energy intensive sector. In developed 
economies, services now account for more than two thirds of total output. In developing countries, services have increased from an average $42 \%$ of output in 1970 to $50 \%$ today [7].

\subsection{Competition}

While all of this suggests that there will be no upsurge in total energy demand to save energy prices, the most direct threat to oil prices in particular is increasing competition from both within and outside the industry.

- Interfuel competition is the first of these. More systematic tracking of gas finds and technological advances in extraction and exploitation now enable exploitation of huge global reserves of natural gas. Gas availability, together with tremendous advances in gas turbines and combined cycle plants has created a very serious competitor to oil as a fuel for electricity provision. More efficient gas-powered production is taking an increased share of the electricity generation market in large part at the expense of oil [8].

- Eventually, even the new fossil fuels will come under challenge - from renewable energy. Costs in photovoltaics have already dropped by about two orders of magnitude in the last 20 years, and are currently competitive with peak-load electricity prices. Already, in order to produce all of the planet's energy requirements, modern solar electric schemes would only need approximately the same area as that currently used worldwide for growing potatoes - about $1 \%$ of the earth's land surface [1]. Wind and other renewables are also likely to reduce the role of oil in direct energy provision in the longer term.

- Intra-industry competition has also played a very big role. One of the most unfavorable forces against high oil prices comes from contestability, which erodes rents. The growth of the Rotterdam spot market and the various crude oil futures and term exchanges, such as the informal Brent market has created opportunities for players to arbitrage away prices that stray above marginal production costs. It has also allowed operators to better manage risk and deal with sudden price spikes, and provided independent market benchmarks.

\subsection{The environmental dimension}

Added to technological and economic pressures on the oil price are environmental concerns. Another factor that could keep oil prices depressed at the well-head, then, is an increasingly large fiscal transfer that penalises consumers for the negative environmental externalities of oil use. This would further swing the advantage to other fuels such as gas and renewables.

Overall, there appears little reason to believe that the last 20 years has seen a dramatic increase in the long-run marginal cost of oil, nor that the future holds out the possibility of its rapid rise. In turn, this suggests that, barring a strong resurgence in the power of an oil cartel, the price of oil over the long term is likely to be, not so much 'depressed,' as 'uninflated'. The Development Economic Division in the World Bank predicted in 1999 that the price of oil will remain below $\$ 14$ as far forward as 2010 . 


\section{What value in low prices?}

What do oil prices that remain close to the long-run marginal cost mean for the four billion people who live in developing countries, and who will provide most of the future growth in energy demand? Clearly, this depends on which country we look at, but overall the effects are likely to be positive.

In general, if prices are above the long-run marginal cost, money that could have been invested in projects with a higher social return will be spent instead on oil extraction or oil substitution. Investments that would have been profitable if energy costs were lower will be abandoned. Instead, money will be spent in the oil sector, on an inappropriately high level of production capacity and on replacements for oil, including synfuels. These investments, with low economic value, will replace those which would have a higher economic return, as it might be information technology, primary school education, or finding a cure for cancer. Overall, the quality and quantity of global output will be reduced.

\subsection{Oil producers}

Some countries appear to be obvious losers, however. What can we say about the impact of lower oil prices on prospects for developing country oil exporters? It is clear that countries such as Nigeria, Algeria, Angola and Venezuela will lose valuable export and tax revenues, and the short-term costs of adjusting to oil price declines might be significant. On the other hand, the examples of Nigeria, Algeria, Angola and Venezuela also suggest that high prices in commodity exports hardly guarantee rapid economic development. Indeed, work by Jeffery Sachs and a team from the Harvard Institute for International Development suggests that the higher the percentage of natural resources exports as a percentage of GDP, the lower the long-term growth. Out of their sample of 97 countries, only two of the top 18 developing countries ranked by growth rates between 1971-89 were rich in natural resources [9].

Why is this? One explanation is Dutch Disease: that high investment in resource extraction and the appreciating exchange rates associated with rapidly increasing resource export receipts deter investment from other sectors with higher long-term growth potential. A second reason is the macro instability caused by the volatility of prices - both windfalls and shortfalls are hard for economies to absorb. Third, there is the temptation toward government expenditure on white elephants and rent-seeking that accompanies oil booms. All of these reasons suggest that low but stable oil prices might be of far more long-term economic value to oil-producing countries than high but volatile prices.

\subsection{Oil consumers}

Oil consumers clearly benefit from lower import bills and this might cause a direct shortterm impact on growth rates. But the results of reduced oil prices are likely to be more far-reaching than that. Low oil prices will make the overhaul of the energy sectors in developing countries more straightforward, providing more consumers with greater choice, and having a positive impact on cleaner energy provision.

Overall, in developing countries an efficient energy sector is central to reducing poverty and promoting sustainable development. This makes sector reform the key to the 
linked problems of energy poverty and environmental risk. Reform hinges on two policies: unbundling inefficient monopolies, and developing private investment. A reformed power sector run by the private sector is more efficient and provides greater consumer choice: nimble private sector operators that are responsive to customers and will offer a richer menu of energy options. This is clear in countries like Argentina, Chile, Cote d'Ivoire and the Philippines, and even in the early stages of reform such as Georgia and Armenia. There, direct contracts for power between suppliers and large customers are providing consumers with comparatively stable, reliable, power supplies.

Low oil prices will help develop this private market. Because operating costs are only a small part of power station expenses, variable fuel costs make up a major portion of the final cost of energy. Erratic electricity prices create risks, especially for those biggest customers who are likely to see energy costs as a significant percentage of their input costs. Stable, low oil prices will allow energy companies to provide stable energy prices to their customers. Thus, private sector provision becomes far more straightforward when customers are creditworthy, and this requires stable prices.

\subsection{End use energy prices}

Energy sector reform involves more than unbundling monopolies and encouraging private investment. Realistic end use pricing is also vital to encourage access to, and sustainable use of, modern energy supplies. Such pricing becomes feasible at a time of lower oil prices. In 1995/6, power subsidies in developing countries were estimated at $\$ 58.3$ billion a year. That figure is equal to over one third of the annual capital requirements for power in those same countries $[10,11]$.

These subsidies do not help the poor. A recent World Bank study in Malawi found that rich consumers get $\$ 6.60$ per year in electricity subsidies, while poorer consumers receive just 4 cents. The poorest, who are unconnected, get no subsidy at all [12]. Yet, subsidisation drains money from programs that could provide investment for rural rollout of modern energy services.

More broadly, the 2 billion people who have no access to electricity spend up to six times the percentage of their income on fuels than do OECD consumers - up to $12 \%$ of their meagre means. The fuel they buy or forage is more expensive, joule for joule (up to six times as costly); less efficient; and more environmentally damaging than modern fuels [13]. For example, wood has 40 times the carbon-hydrogen ratio of natural gas and so burning wood is far more damaging to the global environment, joule for joule, than natural gas-generated electricity [5]. Good pricing policies would have three positive effects. First, they would reduce inefficient and wasteful energy use - the 1992 World Development Report estimated that if electricity price reforms were introduced throughout the Developing World, despite continued economic growth, investment requirements would actually fall from their present levels and not recover until 2010 [10]. Second, proper pricing would provides funds for faster rollout of clean energy supplies to the poor from money saved on subsidies and power plant construction costs, and, third, it would end discrimination against efficient non-grid power sources such as local solar power. 


\subsection{Environmental concerns}

While argument is sometimes made that low oil prices threaten the introduction of renewables and sustainable energy provision, over the long term it is more likely that low prices will encourage sustainable use. This is because:

- prices above the long-run marginal cost are inherently unstable. This makes for a poor investment climate for alternative fuels. The havoc that unstable oil prices can wreak on alternative energy schemes is well illustrated by a Brazilian project that the World Bank backed in the early 1980s. The PROALCOOL alternative energy project was designed to reduce Brazil's reliance on imported petroleum products. Conceived at the very height of the oil price boom, by the time the project was in full production, after the price drops in 1986, it was making an economic rate of return estimated at minus $14 \%$ [14].

- More importantly, the price of renewable energy is competitive today even in a period of low oil prices. If the environmental costs of energy provision were accounted for, renewables would be even more competitive. For example, British Petroleum has just opened its first solar manufacturing facility in California. Wind energy is commercial in countries like Denmark and India. Again, as we have seen, what is slowing the rate of renewable uptake is not the costs of renewables but the institutional structures, the on-grid subsidies and the pure inertia of any large industry so pervasively influenced by outmoded government interventions.

Finally, low oil and energy pricing allows for more rapid reform of the sector and the faster rollout of electricity provision to people unconnected today. This will encourage the rural and urban poor to move from inefficient and carbon-rich fuels to electricity produced in power stations operating under environmental controls, increasingly based on renewable technologies.

\section{Winds of change through the oil companies?}

Low oil prices will encourage reform and renewables in the industry, to the great benefit of developing countries. For oil companies, we are witnessing a shift in value along the chain, from primary energy carriers (such as fuel), to energy services (such as heat and off-grid supply). Profits will increasingly shift from the former to the latter.

Oil companies are faced with a choice as to where they want to position themselves in this changing market. Either they can search out the declining opportunities to gain rents out of the sector, or they can become a highly competitive energy service provider able to generate value whatever the price of oil. Successful companies are likely to take the latter course. This explains the moves of some oil companies to re-position themselves closer to the consumer - one example would be Shell's recent acquisition of Intergen, a major international developer of private power projects. Energy companies, with their knowledge of the field and of customer demand, are also playing an important role in mainstreaming alternative energy sources. Low oil prices do not mean low profits for these companies, they instead suggest that profits will be extracted from different segments and different points on the energy train. Companies that can do this will prosper; companies that rely on rents from their reserves below ground will have an increasingly difficult time. 


\section{Conclusion}

$\mathrm{n}$ of low

an

the

ject

ved

$\mathrm{n}$

the

rage

icity

ased

refit

the

and

:s in

ents

e to

itter

oser

ajor

heir

$\mathrm{e}$ in

for

rent

will

an

Governments have had a very significant effect on the price of energy to the final consumer. In particular, they have done this by manipulating the price of energy inputs in particular, oil and gas. The way they have manipulated prices in the past has been mistaken. Increasing prices at the wellhead and subsidising prices at the socket has had precisely the reverse effect that government policies should have. It has produced incentives that hurt the environment and discriminate against the poor. The reduced market distortions in oil production, reflected by lower prices, provide an opportunity towards reform throughout the length of the energy chain. Reform will lower demand to more rational levels and improve the environmental sustainability of energy provision, while at the same time allowing for expanded energy access.

The virtuous circle of reduced demand and lower prices due to reform, and, in turn, reform leading to reduced demand and lower oil prices, will present challenges to some oil exporting countries and oil companies. But there is enough evidence to suggest that both countries and companies can survive this process and profit from it. The price of oil is not low, then - and the opportunities that a stable price near the long run marginal cost offers to both energy consumers and the environment is a very positive development.

\section{References}

1 Anderson, D. and Ahmed, K. (1993) 'Where we stand with renewable energy', Finance and Development, No.1, November.

2 Maddison, A. (1995) Monitoring the World Economy 1820-1992, Paris, OECD.

3 Anderson, A. (1996) World Oil Trends, Arthur Anderson, London.

4 DeGoyler and MacNaughton (1997) Twentieth Century Petroleum Statistics, Dallas, DeGoyler and MacNaughton.

5 Asubel J. and Longford, H. (Eds.) (1997) Technological Trajectories and the Human Environment, National Academy Press, Washington, DC.

6 World Bank (1998) World Development Indicators, New York, Oxford.

7 UNCTAD (1995) Handbook of International Trade and Development Statistics, United Nations, New York.

8 World Bank (1998) 'Fuel for thought: a new environmental strategy for the energy sector', available on the web at http://www-esd.worldbank.org/cc/.

9 Sachs, J. and Warner, A. (1995) 'Natural resource abundance and economic growth', NBER Working Paper 5398.

10 World Bank (1992) World Development Report: Development and the Environment, New York, Oxford.

11 World Energy Council (1997) Financing the Global Energy Sector: the Task Ahead, The World Energy Council, London.

12 World Bank (1998) Rural Energy and Development for Two Billion People: Meeting the Challenge, The World Bank, Washington.

13 Rischard, J-F. (1998) 'Energy and the World Bank', speech delivered at the World Bank Energy Week Conference, 4 June, Washington, DC.

14 World Bank Operations Evaluation Department (1992) Evaluation Results, The World Bank, Washington. 